\title{
THE EXAMPLE OF LESBIANS: A POSTHUMOUS REPLY TO PROFESSOR MARY JOE FRUG
}

\author{
Ruth Colker
}

The struggle now is how to prevent [Mary Joe Frug's] death from being a premature closure of the work she was pursuing, how to carry on without one of our most exciting and challenging feminist legal theorists. The post-modern talk of "ruptures" and "prying apart crevices" has a horrible, violent ring to me; but we must not let Mary Joe Frug's death stand as the ultimate rejection of her position in a discussion that must, somehow, continue. ${ }^{1}$

Frances OLSEN

\section{INTRODUCTION}

How do you respond to an unfinished manuscript written by a friend who was tragically murdered less than one year ago when you continue to see images of her sitting on a couch talking to you juxtaposed with images of her lying dead on a street in Cambridge? The manuscript is filled with images of violence and death, as if Mary Joe were foreshadowing her own passing from this world. ${ }^{2}$ I want to talk to Mary Joe about the manuscript. What did you mean, here and there? How were you intending to finish it? What troubled you about it that you intended to revise?

On many levels, I cannot read the manuscript at all. I have no idea what Mary Joe intended to say; the image of her death speaks

* Professor of Law, Tulane University.

I met Mary Joe Frug at the New England School of Law in the fall of 1984 when I was seeking a full-time teaching position. She was probably the warmest and most helpful person that I met during my interviews. Had she not extended her encouragement and advice, I might not have continued to pursue a teaching position, and thus might not have been invited to respond to her manuscript. In Judaism, we believe that those who are gone live eternally through their good deeds. I am sure that Mary Joe has a very long life ahead of her through our memories.

I would like to thank John Stick for his helpful comments on an earlier draft, and Lorena Dumas for her diligent research assistance.

${ }^{1}$ Frances Olsen, In Memoriam: Mary Joe Frug, I4 HaRV. Women's L.J. i, vii (I99I).

2 She observes that her notes are often labelled "PM," referring to postmodernism, but that those notes could also refer to premenstrual and postmenopausal blues. See Mary Joe Frug, $A$ Postmodern Feminist Legal Manifesto (An Unfinished Draft), ro5 HARv. L. Rev. I045, I046 (1992). Ironically, they could also refer to "postmortem." 
louder to me than the images evoked by her live written words. As a postmodernist, Mary Joe would have agreed that such symbols and imagery are powerful. Nevertheless, as Professor Fran Olsen has so eloquently articulated, we should not allow Mary Joe's death to end the discussion about her work. In this essay, I have tried to take her work one step further by extending it to the example of lesbians, to whom she alluded in her manuscript through a sentence that was left incomplete by her tragic death. ${ }^{3}$

Professor Frug's Commentary would be much richer if she had been more attentive to the anti-essentialist perspective. Gender essentialism is "the notion that a unitary, 'essential' women's experience can be isolated and described independently of race, class, sexual orientation, and other realities of experience." 4 An anti-essentialist perspective notes that when we speak of "women" unmodified, we are in fact often talking about white, middle-class, able-bodied, heterosexual, adult women. An anti-essentialist perspective tries to talk about women in a way that embraces the important differences among women. ${ }^{5}$

Applying an anti-essentialist perspective to Professor Frug's manuscript reveals that many of the generalizations she makes about women are not accurate when applied to various subgroups of women, such as lesbians. ${ }^{6}$ Professor Frug's central thesis is that law - by permitting and sometimes mandating the sexualization, terrorization, and maternalization of the female body - constructs the female body in three ways. ${ }^{7}$ To support this thesis, she discusses prostitution, family and work, sexuality, and the anti-pornography movement. She had intended to apply these observations to the abortion rights movement as well. ${ }^{8}$ An anti-essentialist perspective reveals that many of the rules that Professor Frug describes as having a negative sexualizing,

${ }^{3}$ Her husband has told me that the sentence discussing lesbians is incomplete because she was writing it when she took her fatal walk. See Letter from Gerald E. Frug, Professor of Law, Harvard Law School, to Ruth Colker, Professor of Law, Tulane University (Nov. I3, I99I) (on file at the Harvard Law School Library).

4 Angela P. Harris, Race and Essentialism in Feminist Legal Theory, 42 STAN. L. REv. $58 \mathrm{I}, 585$ (I990).

5 For further discussion of what I mean by "anti-essentialism," see Ruth Colker, An Equal Protection Analysis of United States Reproductive Health Policy: Gender, Race, Age, and Class, I99I Duke L.J. 324, 326-28. Like Professor Frug, I do not interpret the anti-essentialism perspective as making it impossible for us to generalize about women. Nevertheless, it demands that we be cautious when making those generalizations.

6 Professor Frug tried to embrace anti-essentialism in her own work. Her unfinished attempt to discuss lesbians, for example, see Frug, supra note 2, at 1066, exemplified her acknowledgement of the differences among women. Had she been able to finish her manuscript, she may have made many of the observations that $I$ make in this Commentary.

7 See id. 1049-50.

8 See id. at 1067-68. 
maternalizing, or terrorizing effect on some heterosexual women have an enhanced or different effect on some lesbians. ${ }^{9}$ In some instances, these rules have a similar effect on lesbians and heterosexual women; in others, the effect may be detrimental to heterosexual women, yet it may improve the lives of some lesbians. Nevertheless, the application of an anti-essentialist perspective strengthens Professor Frug's central observation that society constructs women's bodies. This perspective reveals that, although legal rules simultaneously have disparate effects on different groups of women, the rules reinforce a single definition of "femininity." Sojourner Truth's famous response to stereotypes about women's fragility that did not apply to African-American women - "Ain't I a Woman?"10 - is a reminder that certain women have always been excluded from the category "female" to facilitate the socialization of other women as female. Lesbians, the subject of this Commentary, are one example of women who traditionally have been excluded from the category "female."

\section{Sexualization, Terrorization, and Maternalization}

\section{A. Sexualization}

The laws relating to prostitution, Professor Frug argues, sexualize the female body by making women concerned that they are acting like whores. ${ }^{11}$ Women's attractiveness to men comes in part from acting a little, but not too much, like a whore. In addition, she argues that prostitution rules, as well as rules governing social violence and the family, sexualize women by leading them to believe that they must be sexually monogamous. These arguments are premised on the assumption that all sex workers are heterosexual and that all women are sexualized into exclusive, monogamous heterosexuality. By "sexualization," Professor Frug apparently means "heterosexualization" and thereby insufficiently recognizes the lesbian experience in the construction of her arguments.

Heterosexual women are socialized to make themselves attractive to men, and consequently they need to be concerned about the whore stereotype. Some lesbians, ${ }^{12}$ however, do not orient themselves to-

${ }^{9}$ Lesbians are not homogeneous. An anti-essentialist perspective requires that we explore differences among lesbians as well as differences between lesbians and heterosexual women.

10 Elizabeth V. Spelman, Inessential Woman: Problems of Exclusion in Feminist THoUgHT I4 (I988) (quoting Sojourner Truth).

${ }^{11}$ See Frug, supra note 2 , at ro52.

12 I say "some lesbians" because there are many lesbians who try to "pass" as heterosexuals by dressing in a "feminine" manner. Other lesbians who are "out of the closet" also dress in ways that conform to societal norms of femininity and attractiveness. My comments best describe the lesbian who is "out of the closet" and is not trying to conform to societal norms. 
ward men's standards for attractiveness and sexuality. Lesbians receive a different message from prostitution rules than do heterosexual women, because, for lesbians, these rules are part of a larger social order that disapproves of all of their sexual activity. If lesbians are sex workers, they are, like heterosexual women, criminals. Even if lesbians are not sex workers, their private sexual activities may violate criminal laws. ${ }^{13}$ No desired sexual activity is acceptable for a lesbian, regardless of whether she is a sex worker. Prostitution laws highlight the existence and desirability of a certain type of heterosexuality, whereas sodomy laws, along with other regulations, ${ }^{14}$ hide the existence and destroy the desirability of virtually all lesbian sexual activity.

Professor Frug's discussion of the sexualization of sex workers is baffling, because she refers to the stories of lesbian sex workers without recognizing the significance of their sexual orientation. ${ }^{15}$ For example, she cites "one sex worker's description of the discomfort she experienced because she sexually responded to her customer during an act of prostitution."16 Frug concludes that "[h]er orgasm in those circumstances broke down a distinction she sought to maintain between her work and the sexual pleasure she obtained from her nonwork-related sexual activity."17 Frug, however, failed to acknowledge the sex worker's sexual preference. The sex worker to whom Frug referred, Judy Edelstein, has identified herself as a Jewish, lesbian feminist. ${ }^{18}$ Describing her discomfort with having been sexually

13 See, e.g., Bowers v. Hardwick, 478 U.S. I86, I9x ( 1986 ) (upholding the constitutionality of Georgia's sodomy statute as applied to the private, consensual behavior of homosexuals). The Georgia sodomy statute, like most sodomy statutes, could be applied to heterosexuals who engage in anal or oral sex; however, such prosecutions of heterosexuals virtually never occur. (Private sex does not include prostitution). Thus, the United States Supreme Court in Bowers did not reach the issue of whether the Georgia statute could have constitutionally been applied against heterosexuals. Id. at 188 n.2.

14 This Commentary cannot discuss all of the laws that coerce lesbians into making their sexual preference invisible. For example, military regulations force lesbians to remain closeted, see Michelle M. Benecke \& Kirstin S. Dodge, Recent Developments, Military Women in Nontraditional Job Fields: Casualties of the Armed Forces' War on Homosexuals, 13 Harv. WomEN's L.J. 215, 234-38 (I990), and child custody laws coerce lesbians to conceal their sexual orientation to attain or retain custody of their children, see Nan D. Hunter \& Nancy D. Polikoff, Custody Rights of Lesbian Mothers: Legal Theory and Litigation Strategy, 25 BuFf. L. Rev. 69I, 7I4-I5 (1976); Annamay T. Sheppard, Lesbian Mothers II: Long Night's Joumey into Day, 8 WOMEN'S RTS. L. REP. $219,241-43$ (1985).

15 When I refer to lesbians who are sex workers, I am referring to women who sexually arouse men for compensation but who choose women as their sexual partners for uncompensated sex. Although some women sell sex to other women and choose women as their partners for uncompensated sex, I do not discuss such women in this Commentary. Nevertheless, many of my observations could apply to them, because both their public and private sex lives are illegal. Their situation is unique, however, because they do not depend on men for any sexual activity.

${ }^{16}$ See Frug, supra note 2, at 1053 n.7.

17 See id.

18 See Judy Edelstein, Contributors' Notes, in SEX Work: WRITINGS By WoMEN IN the 
aroused by one of her customers, Edelstein remembers thinking: "I just can't believe that I had an orgasm with that jerk. I try to forget him, to think about making love with Laura, the woman I'm with right now. But all I can see is the customer's all-American face."19 Frug interprets Edelstein's discomfort as a work/nonwork discomfort, but it could also have been a heterosexual/lesbian discomfort. I suspect that Edelstein might have been uncomfortable about experiencing sexual pleasure with any man, ${ }^{20}$ regardless of whether he had compensated her for the sexual activity. Edelstein did not seem to be concerned that her whore image from work would intrude into her private life. Instead, she seemed to want to experience her work life as nonsexual, even if the man was receiving sexual pleasure from her. Sex was what she enjoyed with her female lover; work was what she did with men for compensation. ${ }^{21}$

Rather than sexualize Edelstein toward heterosexuality, the laws criminalizing prostitution aided in desexualizing Edelstein. Both her public life - providing sexual services while giving massages - and her private life - lesbianism - were illegal. Law discouraged her from engaging in either activity. Contrary to Professor Frug's thesis, the law criminalizing prostitution did not successfully construct her sexuality in a way that society finds desirable.

Although prostitution rules may not heterosexualize lesbians, other rules may. Professor Frug argues that marriage laws and social rules concerning violence induce women to choose monogamous heterosexuality. ${ }^{22}$ Marriage is structured as a potential source of financial support for women, which makes it a plausible substitute for or supplement to employment. ${ }^{23}$ Social violence induces women to stay married by leading them to rely on individual men - their husbands - for protection against violence. ${ }^{24}$

The marriage rules also affect lesbians. They must choose lesbianism in spite of, rather than because of, these rules. Some lesbians

Sex Industry $34 x$ (Frédérique Delacoste \& Priscilla Alexander eds., 1987) [hereinafter SEX WORK].

19 Judy Edelstein, In the Massage Parlor, in SEx WoRk, supra note 18, at 62, 63.

${ }^{20} \mathrm{I}$ make this statement because Edelstein does not describe herself as a bisexual. See Edelstein, supra note 18 , at $34 \mathrm{I}$.

21 I agree with Professor Frug that Edelstein describes her discomfort with being considered a "whore" in her paid employment. That discomfort may have eventually led her to leave the life of a sex worker. By inducing her to leave, however, society has not succeeded in inducing her to embrace a more acceptable lifestyle of exclusive, heterosexual monogamy.

22 See Frug, supra note 2, at 1062-64.

${ }^{23}$ See id. at 1064.

${ }^{24} \mathrm{See}$ id. at 1064-65. I am not fully convinced by Professor Frug's comments about physical security. See id. In light of the level of violence against women within the family, it is hard to see how a woman's physical safety generally improves by living with a man, even if he occasionally serves as a male escort for her. 
may have relationships with men to obtain the benefits of financial security and safety. ${ }^{25}$ I have always found it interesting to discover the number of women who identify themselves as lesbians (but not bisexuals) who have also had serious relationships with men, including marriage. That pattern seems far less true of men who identify themselves as gay. This sex difference may be the result of women having greater incentives than men to try to be comfortable or happy in heterosexual relationships. Although Professor Frug suggests that it is hard to know how current sexual practices would change if legal rules concerning sexual conduct changed, ${ }^{26} \mathrm{I}$ think the outcome is easy to predict. At a minimum, many more women would seek sexual relations with other women. In other words, given the benefits of the rules that Professor Frug describes, it is surprising that any woman would "choose" lesbianism. Not surprisingly, few women find themselves able to live out such a choice in a system of rules powerfully favoring heterosexuality, monogamy, and passivity.

So how do lesbians manage to defy the powerful force of the rules that Frug describes? As I have discussed elsewhere, the answer lies partly in the "cracks in the wall" of patriarchy. ${ }^{27}$ For example, being a sex worker while also being a lesbian may have been a part of Judy Edelstein's strategy for survival within a patriarchal world, because it enabled her to use men to acquire financial security while not conforming her private life to heterosexual norms. For some women, the occupation of sex worker may serve as a crack in the wall, whereas for other women, the occupation may be a form of subordination and exploitation. By considering the socialization of lesbian sexuality along with the socialization of heterosexual sexuality, we can better understand the full scope of society's construction of the female body and develop law reform strategies to open the cracks wider for a broader range of women.

\section{B. Terrorization}

Prostitution rules, Professor Frug argues, also endanger sex workers' lives and make their work terrifying. Thus, women are induced to choose marriage rather than prostitution. Because she focuses exclusively on heterosexual prostitutes, Frug cannot fully explain why some women become prostitutes, despite the terrorization they face.

25 Professor Frug's discussion of lesbians is incomplete, see id. at Io66, but she clearly understood that economic and safety incentives "make a male partner more advantageous for non-sexual reasons than a same-sex partner for women," id.

26 See $i d$. at 1063 .

27 See Ruth Colker, Feminist Consciousness and the State: A Basis for Cautious Optimism, go Colum. L. REV. I 146, I I60-6I (r9go) (book review). 
Additionally, Frug ignores some legal rules that make prostitution terrorizing.

Lesbians always face terrorization because both their private and public lives are typically illegal. ${ }^{28}$ Moreover, lesbians face the special dangers of violence against lesbian and gay people, regardless of whether they are prostitutes. The terrorization that a lesbian faces as a prostitute is therefore not a unique problem in her life. For a heterosexual woman, however, marriage may be less terrorizing than prostitution. The differential rate of terrorization in the public and private life of a heterosexual prostitute may act as a stronger deterrent to engaging in prostitution than it would for a lesbian. The existence of prostitution despite terrorization may be explained best by understanding how society makes the lives of certain undesirable women (for example, lesbians, poor women, women of color) so dangerous that the terrorization inherent in prostitution is an "acceptable" danger.

Professor Frug would have better understood the terrorization element in all prostitutes' lives if she had investigated sodomy statutes - an area of the law that is often thought to be inapplicable to heterosexual activity - along with prostitution regulations. (Frug's list of six areas of the law that terrorize prostitutes omits sodomy statutes). ${ }^{29}$ Sodomy statutes permit the state to enhance the penalty for prostitution by also bringing a sodomy prosecution, ${ }^{30}$ despite the fact that unprotected intercourse presents a more serious risk of HIV infection for a female prostitute and her client than sodomy (for example, oral sex). ${ }^{31}$ Although sodomy statutes are an important aspect of the terrorization that many prostitutes face, they are rarely a part of feminist law reform discussions concerning prostitution. A heterosexual perspective makes it easy to overlook laws normally associated with lesbian and gay sexual activity, but which actually affect all women.

\section{Maternalization}

Finally, Professor Frug describes how prostitution rules, work rules, and family law rules maternalize women. Many of these rules have a dematernalizing effect on lesbians. A crucial difference between lesbians and heterosexual women is the application of the maternal stereotype. Heterosexual women are viewed as presumptively

${ }^{28}$ See supra notes $\mathrm{x}_{2}-\mathrm{I}_{4}$ and accompanying text.

${ }^{29}$ See Frug, supra note 2, at 1054.

30 See, e.g., Louisiana v. Neal, 500 So. $2 \mathrm{~d}$ 374, 376 (La. I987) (affirming a conviction of the codefendant for a crime against nature and prostitution).

31 Although studies have found that oral sex is not a major source of transmission of the HIV virus, it presents some risk unless a condom is used. See, e.g., Marsha F. Goldsmith, As AIDS Epidemic Approaches Second Decade, Report Examines What Has Been Learned, 264 JAMA 43I, 433 (1990); Letter from Dr. John Petricciani, 262 JAMA 223I, 223I (1989). 
maternal, whereas lesbians are viewed as unsuited and unable to bear children. For example, I once shared with a male colleague the fact that I was considering pregnancy. At the time, I was intimately involved with a woman. My colleague was shocked by the idea that I could become pregnant. He seemed to assume that my involvement with a woman had destroyed my biological capacity to bear children. Since I have become intimately involved with a man, however, no one has reacted with surprise to my pregnancies. Somehow, my uterus was figuratively returned when my sexual partner changed from a woman to a man. Similarly, when I have debated lesbian and gay rights issues, my opponent has often assumed that the only way a lesbian could obtain custody of a child was through adoption. I must therefore point out that lesbians can also obtain children through childbirth. However, the law goes to great extremes to separate lesbians and gay men from children. For example, even a jurisdiction such as Denmark, which recognizes lesbian and gay marriage through a registered partnership act, has withheld the benefits of adoption from "married" gay couples. ${ }^{32}$ Similarly, our laws and rules with respect to artificial insemination have historically restricted lesbians from eligibility. ${ }^{33}$

Another source of the dematernalization of lesbians is our familybased workplace rules - rules that Professor Frug describes as maternalizing women. Professor Frug argues that discrimination against women in the workplace makes it more likely that women will leave the workplace to raise and care for children. Other family-based workplace rules, however, dematernalize lesbians, not because they discriminate against women generally, but because they discriminate on the basis of sexual orientation. For example, employer-based health insurance is made available exclusively on a family and class ${ }^{34}$

32 See Nan D. Hunter, Marriage, Law, and Gender: A Feminist Inquiry, I LAW \& SEXUALITY: REv. LESBLAN \& GAY LEGaL Issues 9, IO-I I n.3 (I9gI). Similarly, when Massachusetts passed a gay rights statute, opponents of the statute argued that lesbian and gay people should not be able to adopt children under the auspices of the statute. A compromise was eventually reached in which an amendment was added that would, on its face, appear to apply to both gay and straight people if their sexual orientation were "an obstacle to the psychological, or physical well-being of the child." Joyce P. Cain, Massachusetts' 1989 Sexual Orientation Nondiscrimination Statute, I LAw \& SEXuality: REv. LESBIAN \& GAY LEGal Issues 285, 298 n.93 (1991). The legislatures in New Hampshire and Florida have passed legislation barring lesbians and gay men from adopting children. See In re Opinion of the Justices, 530 A.2d 2 I, 25 (N.H. 1987) (holding that a proposed New Hampshire law that prevented homosexuals from adopting children or becoming foster parents did not violate the Constitution); Seebol v. Farie, No. 90-923-CA-I8 (Fla. Cir. Ct. Mar. Io, I991) (overturning Florida's ban on gay adoptions).

${ }^{33}$ See Barbara Kritchevsky, The Unmarried Woman's Right to Artificial Insemination: A Call for an Expanded Definition of Family, 4 HARv. WoMEN's L.J. I, 3, I7 (Ig8I).

${ }^{34}$ Professor Frug's discussion of workplace rules typically describes rules that affect middleclass workers who are able to obtain benefits such as health insurance. Workers who receive few, if any, job-related benefits would not be maternalized by many of the rules described by Professor Frug. 
basis, and thus the lesbian family is excluded from recognition and coverage. Consequently, it is more difficult for a middle-class lesbian couple to afford to bear and raise a child than it is for a middle class heterosexual couple to do so. Our health insurance rules make it financially feasible for some heterosexual women to leave the workplace to raise children while they retain coverage under their husband's plan. Those same rules make it financially difficult for a lesbian to make a comparable choice, because the parent that stops work to care for the child cannot obtain insurance through her partner.

Family law rules, however, sometimes serve to maternalize lesbians, as well as heterosexual women. Frug assumes that maternalization through legal rules is always bad for women. For lesbians, maternalization could be beneficial. For example, Frug argues that it is harmful for women to be maternalized through rules that favor women's parenting roles. But for lesbians, who often face nonmaternal stereotypes in the courtroom, ${ }^{35}$ a legal presumption that they could be good parents might be beneficial. ${ }^{36}$ If the maternal presumption were applied to lesbians, it might make it easier for them to undermine the courts' stereotypes with respect to their fitness as mothers. Without that presumption, they are simply, like prostitutes, unwelcome criminals.

\section{Application to LaW Reform: The ANTi-PoRnography Campaign and THE ABortion Rights Movement}

An anti-essentialist perspective can also promote effective law reform strategies. Professor Frug makes the connection between the theoretical and the practical by showing how her thesis applies to the MacKinnon/Dworkin anti-pornography campaign. She hopes that examining the ordinance campaign closely will help "advance the prospects of an abortion reform effort that the Supreme Court might thrust upon us." 37 One familiar criticism of the ordinance effort, she argues, is the alliance between feminist ordinance advocates and nonfeminist conservatives. Frug, however, claims that this alliance is positive, because it "successfully engage[s] nonfeminist political camps."38 She acknowledges that this engagement came at the expense of feminist

${ }^{35}$ See, e.g., Hunter \& Polikoff, supra note I4, at 705-I4; Sheppard, supra note 14, at 24I43.

${ }^{36}$ See, e.g., In re Diehl, No. 2-90-1217, 1991 Ill. App. LEXIS 1972, *22 (Ill. App., Nov. 22 , I99I) (denying custody to an alleged lesbian by applying a reverse tender years presumption and stating that because of the child's "tender years . . . it is in her best interest not to be exposed to a lesbian relationship," but overturning restrictions on visitation imposed by the trial court).

37 Frug, supra note 2, at 1068.

38 Id. at 1070. 
unity, but "that breaching this unity is a necessary component of feminist efforts against women's oppressions." 39

Clearly, coalition building is important in any political campaign. However, Professor Frug does not sufficiently probe the basis of the political differences in the anti-pornography ordinance campaign. Among the feminist critics of the ordinance were lesbians who voiced concerns that the ordinance's broad definition of pornography would limit their ability to experiment with new forms of sexuality through the use of pornographic materials. ${ }^{40}$ They argued that women have been socialized to be sexually passive and therefore to partake only in what was described as "vanilla" (or bland) sexual behavior. Within a lesbian relationship, in which both partners have been socialized in this manner, that problem can be quite acute. Hence, these critics feared that the "Vanilla-Sex Gestapo"41 would try to encourage lesbians to be even more sexually passive.

Professor Frug's attribution of this disagreement to differences in postmodern philosophy ${ }^{42}$ is inaccurate. As postmodernists, critics of the ordinance understood that the images of sexuality that they might create with their own pornography might help women escape vanilla sex. ${ }^{43}$ They wanted to use pornography constructively. Because they were a distinct and invisible feminist minority that had come forward to raise specific objections, the ordinance organizers had an obligation to listen to them and compromise with them to overcome the prevailing essentialist understanding of women's views concerning pornography. It was especially important for the feminist proponents to consider the views of the feminist critics, because the critics agreed with the basic postmodern premise of the movement - that pornography can have a transformative effect on society.

There is an instructive analogy to the abortion rights movement. For more than a decade, African-American feminists have been saying that the abortion rights movement has not been speaking to their concerns; ${ }^{44}$ that pro-choice leaders have not paid sufficient attention

${ }^{39} \mathrm{Id}$. at 1070.

40 For an excellent collection on the sex debate, see Pleasure and Danger: Exploring Female Sexuality (Carole S. Vance ed., I984). Many of my comments stem from several conversations with lesbians regarding the anti-pornography movement.

41 I have found the term "vanilla sex" in lesbian literature. See, e.g., Martha Equinox, If I Ask You to Tie Me Up, Will You Still Want to Love Me?, in Coming To PoWER: Writings AND GRAPHICS ON LESBIAN S/M 29, 3 I (SAMOIS ed., 1982) (distinguishing between sadomasochistic sex and "vanilla sex"). I have not, however, found the term "Vanilla-Sex Gestapo," which I presume is original to Mary Joe. Frug, supra note 2, at royo.

42 See Frug, supra note 2, at 1070.

${ }^{43}$ See Nan D. Hunter \& Sylvia A. Law, Brief Amici Curiae of Feminist Anti-Censorship Taskforce, et al., in American Booksellers Association v. Hudnut, 21 U. Mich. J.L. REF. 69, 69-75, 102-05, 128-32 (1987-1988).

44 See, e.g., ANgeda Y. Davis, Women, RACE ANd Class 202-2I (Ig81). 
to forced sterilization, lack of prenatal care, lack of support for children in poverty, and other policies that limit the choices of poor women. For example, white feminists did not respond with much of an outcry when Harris $v . M c R a e^{45}$ was decided, and yet we anticipate a feminist riot if Roe $v$. Wade $e^{46}$ is overturned. Instead of addressing the full range of choices in women's lives, the abortion rights movement has focused narrowly on the single issue of the formal right to "choose" an abortion, while it continues to ignore issues of affordability. ${ }^{47}$ It is not enough for the movement's leadership to acknowledge splintering among women on the abortion issue. Instead, feminists need to ask whether particular groups of disadvantaged women have been left out of the feminist union by the essentialist way in which the priorities of the movement have been constructed.

Professor Frug's argument that the ordinance campaign should have attempted to deconstruct pornography rather than destroy $\mathrm{it}^{48}$ has important implications for the abortion rights movement as well. Frug criticizes the ordinance campaign for being too male in its language and rhetorical style. This final observation by Professor Frug brings her in seeming agreement with the feminist critics of the ordinance. Both were trying to open the discussion of pornography beyond the simplified picture offered by the ordinance advocates. Unfortunately, the feminist critics also used highly dichotomized and hierarchical arguments in expressing their views. But one might argue that they had no choice - it is difficult to respond to a male style of argumentation in a female style. 49

What, then, is the appropriate lesson for the abortion rights movement? In my own work, I have tried to encourage less dichotomized discussions about issues related to abortion. ${ }^{50}$ We need to consider, for example, how "choice" and "life" are not bipolar opposites. Women who choose abortions or choose to forego medical intervention during their pregnancies often make those choices out of a respect for life, including the lives of their families, their future children, and themselves. ${ }^{51}$ I hope that Professor Frug's manuscript will inspire us to

45448 U.S. $297,326-27$ (I980) (upholding congressional limitations on Medicaid payments for abortions).

46 4IO U.S. II3 (I973).

47 For a discussion of the abortion issue in a reproductive health context, see Colker, supra note 5 , at $346-50$.

48 See Frug, supra note 2, at ro72.

${ }^{49}$ For further discussion of this dilemma, see Ruth Colker, Feminist Litigation: An Oxymoron? - A Study of the Briefs Filed in William L. Webster v. Reproductive Health Services, I3 HARV. WOMEN's L.J. I37, I37-68 (1990).

50 For further discussion, see Ruth Colker, Abortion and Dialogue: Pro-Chotce, ProLIFE, AND AMERICAN LAW (Indiana University Press, forthcoming 1992) (on file at the Harvard Law School library).

${ }^{51}$ See id. 
find ways to join in public debates in less polarized ways than we adopted during the anti-pornography and abortion rights movements.

\section{Conclusion}

Professor Frug's manuscript has helped me see more clearly how legal doctrine constructs women's bodies by sexualizing, terrorizing, and maternalizing them. Unlike other feminists who have focused on one or the other of these issues, she has brought them together in one complete work. Rather than being a "linchpin" theorist, she has clarified the variety of ways in which law maintains and constructs subordination of women through law.

My critique reflects a concern with the extent to which she deviated from her original intention - to provide us with a "localized disruption" rather than a total theory. ${ }^{52}$ Many of the rules that she describes have an opposing or enhanced effect on lesbians. Through a more complete exploration of the diversity of women's experiences, a sharper image of the actual operation of female socialization might emerge. Certain women are oversocialized as female whereas other women are excluded from the category altogether. It is through this combination of effects that socialization steers women toward femininity.

Thank you, Mary Joe, for providing us with many insights in your thoughtful essay. The discussions with you must continue.

52 Professor Frug attempted to write a "localized disruption" rather than a total theory, see Frug, supra note 2, at I046. She seems to have been influenced by Catharine MacKinnon's work, see id., although MacKinnon attempts to formulate a "total theory" rather than a localized disruption. See, e.g., Catharine A. MacKinnon, Feminism, Marxism, Method, and the State: An Agenda for Theory in FEMINIST THEORY I, 6 n.7 (Nannerl O. Keohane, Michelle Z. Rosaldo \& Barbara C. Gelpi eds., 1982) ("I aspire to include all women in the term 'women' in some way, without violating the particularity of any woman's experience."). The reference to Mackinnon is baffling to me, except to suggest that Professor Frug was possibly torn between writing a total theory and writing a localized disruption. 